\title{
Nutritional Evaluation of Seed and Characterization of Crude Jack Bean (Canavalia ensiformis) OIL
}

\author{
Abitogun, A. S. ${ }^{1}$, Olasehinde, E. F. ${ }^{2}$. \\ ${ }^{I}$ (Department of Science Laboratory Technology, Rufus Giwa Polytechnic, Owo, Nigeria) \\ ${ }^{2}$ (Department of Chemistry, Federal University of Technology, Akure, Nigeria)
}

\begin{abstract}
The Canavalia ensiformis used for this study was cultivated and harvested in Owo, Ondo state of Nigeria. The seed was prepared by sun drying for two weeks; it was later dehulled and milled to flour. The proximate and the mineral compositions of the seed were investigated using standard analytical techniques. The oil in the seed was extracted using solvent extraction method. The resulting crude oil was assessed for physicochemical parameters and fatty acid composition. Canavalia ensiformis contains high protein content, high carbohydrate content, high fibre content, low lipid and adequate minerals. The oil was bright in colour, transparent with low thermal stability when in contact with air. The free fatty acid and acid value was low, have high iodine and peroxide values, and low saponification value. Oleic acid has the highest fatty acid composition with $32.88 \%$, followed by Linoleic acid with $25.93 \%$. The total saturated fatty acid was $8.41 \%$, while the total unsaturated fatty acid was $86.49 \%$. Having considered the proximate and mineral compositions, the study revealed that the seed have high potential for animal and human consumption. In addition, it compared favourably with some conventional edible legumes. The oil, if refined and consumed will supply essential fatty acid to the body based on the fatty acid composition.
\end{abstract}

Keywords: Canavalia ensiformis, Physicochemical, Mineral, Proximate, Oil

\section{INTRODUCTION}

Large population in developing countries suffers differing degree of malnutrition because protein rich food such as meat, milk, fish were expensive to acquire. In response, many food scientists were focusing on legumes in an effort to develop nonconventional protein source and apply them as nutritional ingredients [1, 2]. Apart from this, there are some wild leguminous plants whose potential have been exploited [3]. The importance of legumes in the diets of man and animal cannot be overemphasized. The role it plays in developing countries has been well documented [4]. They are rich in nutrients such as digestible protein with good array of amino acids minerals [5]. Most of these wild seeds have been reported to be a good source of oil and they contain essential fatty acids [6]. Leguminous seed have been reported to be excellent sources of energy $[4,7]$ in animal and human diets. Many wild vegetables, even weeds of agriculture are highly rich not only in protein but also in Calcium, Iron and Vitamin A [8]. Various studies are being carried out to assess the protein potential of legumes that are still not widely used as dietary sources of protein, as well as a genetic resource for the improvement of traditional legume crops [9].

Canavalia ensiformis, commonly known as Jack bean, is usually used in Nigeria as an ornamental plants, grown near houses and allowed to trail on walls and trees [10]. It is the most common shrub in the North coast of Columbia [11]. Jack bean belongs to the kingdom Plantae, division magnoloiphyta, order fabales, family fabaceae, Genus Canavalia and species Canavalia ensiformis [12]. The information on the nutritional composition is limited; in fact, little information was reported concerning the physicochemical properties of the oil. This study therefore, is designed to provide analytical data on proximate, mineral and functional properties of the seed as well as physicochemical composition of the oil extracted from the seed.

\section{MATERIALS AND METHOD}

The matured pods of Canavalia ensiformis was harvested from a lawn located in Owo, Ondo State, Nigeria. It was manually opened to remove the seeds, which were sundried for about 10 days. The shell was removed before milling to flour. A soxhlet extractor was used for extraction of the oil. The solvent used was petroleum ether which was recovered by simple distillation. The residual oil collected was referred to as crude oil. Both the seed flour and the crude oil were used for analytical work.

The proximate analysis of the samples which were: moisture content, ash content, crude fibre and crude fat were carried out in triplicate using standard analytical methods [13]. The nitrogen content was determined by the micro kjeldah method [14], and the nitrogen content was converted to protein by multiplying by a factor of 6.25. Carbohydrate content was determined by difference, that is, 100 minus crude protein, crude fibre, ether extract, moisture content and ash content. 
The minerals were determined by dry-ashing the sample at $550^{\circ} \mathrm{C}$ to constant weight and dissolving the ash in a volumetric flask, using distilled and deionized water with a few drops of concentrated hydrochloric acid. Sodium and potassium were determined by using a flame photometer with $\mathrm{NaCl}$ and $\mathrm{KCl}$ to prepare the standards, while other parameters were determined using Atomic Absorption Spectrophotometer [15]. The macro minerals were reported in $\mathrm{g} / 100 \mathrm{~g}$, while the micro minerals were reported in $\mathrm{mg} / 100 \mathrm{~g}$.

The moisture content and specific gravity were determined according (AOAC, 1992), while the refractive index was determined using Abbey Refractometer. The colour was determined using Lovibond Tintometer in one Inch cell [15]. The Flash point, Fire point Smoke point and Turbidity were determined by standard method [15].

The chemical parameters were equally determined by official method of analysis [13]. The chemical parameters determined were free fatty acid, acid value, saponification values, peroxide value and iodine value. The analytical test method for fatty acid methyl ester were carried out using Agilient 6890 series, Gas chromatograph filled with a flame ionization detector and enhanced integrator. Helium gas was used as carrier gas. The column initial temperature was $250^{\circ} \mathrm{C}$ rising $10^{\circ} \mathrm{C} / \mathrm{mm}$ to a final temperature at $300^{\circ} \mathrm{C}$, while the injector and the detector were maintained at $250^{\circ} \mathrm{C}$ and $300^{\circ} \mathrm{C}$ respectively. The peak was identified by comparing with standard fatty acid methyl esters [15].

\subsection{Results}

\section{RESULTS AND DISCUSSION}

Table 1: Proximate composition of Canavalia ensiformis seed flour

\begin{tabular}{ll} 
Parameters & Results in g/100g \\
\hline Moisture content & $2.19 \pm 0.32$ \\
Protein content & $20.97 \pm 0.51$ \\
Crude fibre & $2.55 \pm 0.15$ \\
Ash content & $3.45 \pm 0.96$ \\
Ether extract & $10.23 \pm 1.61$ \\
Carbohydrate & $60.61 \pm 2.51$
\end{tabular}

Mean \pm standard deviation of triplicate determinations

Table 2: Mineral composition of Canavalia ensiformis seed flour

\begin{tabular}{lc} 
Minerals & Concentrations $(\mathbf{g} / \mathbf{1 0 0 g})$ \\
\hline Sodium (Na) & 2.53 \\
Potassium (K) & 5.92 \\
Calcium (Ca) & 3.21 \\
Magnesium (Mg) & 1.95 \\
Phosphorus (P) & 1.50 \\
Zinc ( $\mathrm{Zn})$ & 2.90 \\
Iron (Fe) & 0.83 \\
Manganess (Mn) & 0.35 \\
Copper $(\mathrm{Cu})$ & 0.43 \\
Lead $(\mathrm{Pb})$ & 0.14 \\
\hline
\end{tabular}

Table 3: Physicochemical Parameters of crude Canavalia ensiformis Crude Oil

\begin{tabular}{ll} 
Parameters & Results \\
\hline Specific Gravity & $0.92 \pm 0.00$ \\
Refractive Index & $1.46 \pm 0.41$ \\
Colour (units) & $7.00 \pm 0.00$ \\
Moisture content $(\%)$ & $1.22 \pm 1.02$ \\
Flash point $\left({ }^{\circ} \mathrm{C}\right)$ & $199.30 \pm 2.10$ \\
Fire point $\left({ }^{\circ} \mathrm{C}\right)$ & $300.20 \pm 2.50$ \\
Smoke point $\left({ }^{\circ} \mathrm{C}\right)$ & $166.00 \pm 5.40$ \\
Soft point $\left({ }^{\circ} \mathrm{C}\right)$ & $17.3 \pm 0.50$ \\
Turbidity $(\mathrm{Jtu})$ & $145.00 \pm 0.72$ \\
Free fatty acid (\% oleic acid) & $3.20 \pm 0.72$ \\
Acid value $(\%$ oleic acid) & $6.40 \pm 1.42$ \\
Saponification value (mg KOH/100g oil) & $196.50 \pm 1.40$ \\
Peroxide value (meq. Peroxide/kg) & $18.30 \pm 0.10$ \\
Iodine value & $67.20 \pm 0.26$ \\
\hline
\end{tabular}

Mean \pm Standard Deviation of triplicate determinations. 


\begin{tabular}{llll} 
Table 4: Fatty acid compositions of Crude & Canavalia ensiformis Oil \\
Fatty acid methyl ester & Fatty acids & Carbon number & Results (\%) \\
\hline Caprilate & Caprylic & $8: 00$ & 0.04 \\
Capritate & Capric & $10: 00$ & 0.09 \\
Laurate & Lauric & $12: 00$ & 0.05 \\
Myristate & Myristic & $14: 00$ & 4.85 \\
Palmitate & Palmitic & $16: 00$ & 3.08 \\
Palmitolate & Palmitoleic & $16: 01$ & 18.97 \\
Stearate & Stearic & $18: 00$ & 0.05 \\
Oleate & Oleic & $18: 01$ & 32.88 \\
Linoleate & Linoleic & $18: 02$ & 25.93 \\
Linolenate & Linolenic & $18: 03$ & 8.71 \\
Arachideate & Arachidic & $20: 00$ & 0.25 \\
\hline
\end{tabular}

\subsection{Discussion}

Table 1 gives the result of the proximate composition of Canavalia enciformis seed. The result in $\mathrm{g} / 100 \mathrm{~g}$ was: protein $(20.97 \pm 0.51)$, ash content $(3.45 \pm 0.96)$, ether extract $(10.23 \pm 1.61)$, crude fibre $(2.55 \pm 0.15)$, moisture content $(2.19 \pm 0.32)$ and carbohydrate $(60.61 \pm 2.51)$. Proteins are essential component of diet needed for the survival of animals and humans, their basic function in nutrition is to supply adequate amount of amino acids [3]. The seed under study was rich in protein like other leguminous plants. The protein content compares favourably with $21.90 \%$ reported for Phaseolus vulgaris, $20.60 \%$ for Cicer arietium, $22.4 \%$ for Cajana cajan $22.20 \%$ reported for Hura crepitans [16-18]. However, it was less than $29.90 \%$ reported for Pisum sativum and $26.20 \%$ for some selected varieties of Cowpeas [19]. The values obtained for crude protein in this study was an indication that the seeds might be useful in the formulation of animal feeds.

The ash content gives an idea of the amount of inorganic content of the sample from where the mineral contents could be obtained. The values obtained for ash content was within the range $1.63-8.53 \mathrm{~g} / 100 \mathrm{~g}$ reported for commonly consumed fruits and some selected varieties of Cowpeas [20]. Samples with higher percentage of ash content were expected to have high concentrations of various mineral elements, which were expected to speed up metabolic processes and improve growth and development. However, the value obtained for ash content was less than 5.80\% reported for Cajanus cajan [17].

The ether extract was low in the seed implying that the oil content of the seed was low. Ether extracts are essential because they provide the body with maximum energy; approximately twice that for equal amount of protein and carbohydrate [21]. The ether extract was less than 18-20\% reported for some selected seeds and nuts such as Soy bean, Sunflower, Safflower and Peanut [22-23]. The low level of ether extract in the seed implies that the seed might not be a good source of oil which means that the oil in seed could not be commercially extracted and refined to edible vegetable oil. However, the oil content was higher than 1.404.0.00\% reported for processed Vigna unguiculata and 2.60\% reported for Cajana cajan [17, 24]. Fibre helps in the maintenance of human health and has been known to reduce cholesterol level in the body. The value obtained for fibre was in line with the value obtained for some selected varieties of Cowpeas and the fibre content was less than some African fruits [25].

The moisture content was low suggesting that the seed might be able to withstand long period of storage and transportation. The carbohydrate content was high suggesting that the seed would be a good source of carbohydrate. The high carbohydrate contents indicate that it might be a good supplement to scarce cereal grains as sources of energy in feed formulations [25].

Table 2 depicts the mineral compositions of Canavalia ensiformis seed flour in $\mathrm{g} / 100 \mathrm{~g}$. The macro minerals detected in the sample and their values were: Sodium (2.53), Potassium (5.92), Calcium (3.21) and Magnesium (1.95). The micro minerals detected in $\mathrm{mg} / 100 \mathrm{~g}$ were: Iron (0.83), Copper (0.43), Manganese (0.35), Lead (0.14), Zinc (2.90) and Phosphorous (1.50). Potassium has the highest value followed by Calcium. Potassium plays important role in lowering the risk of high blood pressure [26]. Calcium is concerned with nerve impulse transmission, muscle contraction and blood clotting. This justifies the incorporation of the seed in formulation of food for animal and human consumption.

Magnesium is an essential component of Chlorophyll in green plants and oxidation of enzymes in animals, like Potassium, it is lost from cells in states of chronic water and salt loss from the tissue fluids and blood, as in some long-standing intestinal disease with diarrhea. Normally about $300 \mathrm{mg}$ is present in normal diet [26]. The value obtained for Magnesium would supply this concentration if added to food mills. Only occasionally have human been found to have Manganese deficiency. An average human being contains 10$20 \mathrm{mg}$, a quarter of which is found in bone, the rest being uniformly distributed in tissues [26, 27]. The Manganese in the seed would only compliment the Manganese in human body. Phosphorous take secondary role in bone formation, however, the deficiency results in series of bone diseases. Zinc is said to be an essential trace element for protein and nucleic acid synthesis and normal body development [28]. It is a component of many 
enzymes such as Carbonic anhydrase, essential for normal body function and the seed could supply the 12 $\mathrm{mg} /$ day which is the required dietary allowance (RDA) [29].

Table 3 gives the result of the physicochemical parameters of Crude Canavalia ensiformis oil sample. The moisture content was determined to be $1.22 \pm 0.02$, the presence of moisture might be as a result of the efficiency of the Soxhlet extractor and/or, it might be as a result of experimental error. The colour of the crude oil was determined to be $7.00 \pm 0.00$ lovibond units. The bright colour of the crude oil might be as a result of low level of Red pigment present in the oil. The colour was similar to 7 lovidond units reported for bleached Soy bean oil [22]. The colour was less than 18.00 units for crude Soy bean oil, 20.00 units for crude Cajanus cajan oil and 25.00 units for crude Shea Butter [22, 24, 30]. The specific gravity of the oil was determined to be 0.92, this value agrees with the value obtained for crude oil of Sunflower, crude Soy bean oil as reported by [22-24]. However, it was higher than 0.87 reported for crude Luffa cylindrica oil [6]. The Refractive index was $1.46 \pm 0.01$ which was in consonance with the value range of 0.472 to 1.476 for edible oils as reported by [31]. The Smoke, Flash and Fire points were the standard measures of its thermal stability when heated in contact with air. The result of the smoke, flash, fire points were $166.00 \pm 5.40^{\circ} \mathrm{C} 199.30 \pm 2.10^{\circ} \mathrm{C}$ and $300.30 \pm 2.10^{\circ} \mathrm{C}$, respectively. This implies that the oil was a low molecular weight oil since the values was less than $420^{\circ} \mathrm{C}$, $620^{\circ} \mathrm{C}$ and $670^{\circ} \mathrm{C}$ for Smoke, flash and fire points respectively, which was reported for high molecular oils. This result suggests that the oil might possess low combustion characteristics. The soft and cloud points were determined to be $17.3 \pm 0.5^{\circ} \mathrm{C}$ and $-3.00 \pm 0.00^{\circ} \mathrm{C}$ respectively. The turbidity value was $145.00 \pm 0.72 \mathrm{Jtu}$, implying that the oil was transparent and clear. However, it was higher than 10.00jtu reported for Luffa cylindrica oil [6]. Free fatty acid and acid value are among the characteristics that are necessary for the confirmation of the identity and edibility of the oil. The free fatty acid and the acid value were determined to be $3.20 \%$ oleic acid and $6.40 \%$ oleic acid respectively. The values were indications that the oil can be refined to edible vegetable oil. Since most fatty acids present in natural fats are not soluble in water, some have relatively high fatty acids, while some show low fatty acids [32]. These values were within the range values of $1.00-5.00 \%$ reported for crude soybean oil [23, 33]. However, the values were higher than 1.40\%oleic acid and 3.09\%oleic acid reported for crude Sunflower oil [22].

The peroxide value was determined to be $18.30 \pm 0.10(\mathrm{mEq} / \mathrm{peroxide} / \mathrm{kg})$. The peroxide value is indication that the oil would be susceptible to oxidative rancidity, which gives an insight to presume that the oil contains high level of unsaturated hydrocarbon. However, the peroxide value was higher than $12.60 \mathrm{mEq} / \mathrm{peroxide} / \mathrm{kg}$ reported by [22], and less than $21.38 \mathrm{mEq} / \mathrm{peroxide} / \mathrm{kg}$ for crude Soy bean oil, both contain unsaturated fatty acids. The Saponification value was $196.5 \pm 1.0 \mathrm{mgKOH} / \mathrm{g}$ oil, which is in range with $190.00-210.00 \mathrm{mgKOH} / \mathrm{g}$ oil reported for crude Soy bean oil $[23,33]$. This value suggests that the sample might be of low molecular weight fatty acid triglyceride. The value was also very close to $197.43 \mathrm{mgKOH} / \mathrm{g}$ reported for crude Sunflower oil [24], suggesting that the oil might not find application in soap and shampoo industries. However, this value is higher than $179.52 \mathrm{mgKOH} / 100 \mathrm{~g}$ reported for Luffa bean oil [6]. The unsaturated glyceride of oil is the ability to absorb a definite amount of iodine [31,34]. The iodine value was determined to be $67.2 \pm 0.26 \mathrm{mg} / 100 \mathrm{~g}$. The level of the iodine value gives an insight to presume that the oil contains high level of unsaturated hydrocarbons and it will not be stable in air at ordinary temperature. This shows that it is a nondrying oil, and does not congeal at ordinary temperature after several days. Therefore, the oil may find its application in the manufacturing of lubricants, hydraulic fluids and coating [35].

Table 4 gives the fatty acid composition of crude Canavalia ensiformis oil. The fatty acids detected and their values were: Caprylic acid 0.04, Capric acid 0.09, Lauric acid 0.05, Myristic acid 4.85, Palmitic acid 3.08, Palmitoleic acid 18.97, Stearic acid 0.05, Oleic acid 32.88, Linoleic acid 25.93, Linolenic acid 8.71, and Arachidic acid 0.25. All the fatty acids detected were in crude Soy bean oil, crude Safflower oil and crude Sunflower oil [22, 33]. Caprylic acid and Capric acid were the additional fatty acids detected in the sample. The values obtained for Caprylic acid and Capric acid was less than $1.3 \%$ and $4.14 \%$ respectively reported for crude Ginger oil [36]. Fatty acid composition is used for classification of oil, depending on the predominant type of fatty acid. In this regard, the oil under investigation can be classified as high oleic acid, based on the high content of Oleic and Linoleic acids. The value obtained for Linoleic acid compared favourably with $27.8 \%$ reported for Sunflower oil, while the linolenic acid value was higher than $0.04 \%$ determined for Sunflower [37]. The summary of the fatty acids in the oil were as follows: total saturated fatty acids was $8.41 \%$; total unsaturated fatty acids was $86.49 \%$, the total fatty acids was $94.90 \%$. The $5.10 \%$ was the value for fatty acids in the oil sample that was not detected. This might be as a result of impurities present in the crude oil.

\section{CONCLUSION}

The study revealed that the seed has high potential for animal and human consumption, having considered the proximate and mineral composition. In addition, it compares favourably with some conventional edible legumes. The results of the various investigations on crude Canavalia ensiformis oil suggest that the oil could be refined and consumed by human being and if consumed, it will supply the essential fatty acids needed in the body based on the results of the fatty acid composition of the oil. The results of the physicochemical 
properties further support the suitability of the oil for consumption rather than industrial application for soap making.

\section{References}

[1] Y. A. Adebowale, I. A. Adeyemi and A. A. Oshodi, Functional and physicochemical properties of flours of six Mucuna species. Africa Journal of Biotechnology, 4, 2005, 1461-1468.

[2] A. A. Adeniyi and S. Ehiemere, Effect of replacing maize with Sorghum offal in the diets of weaner rabbits. J. Agric. Res. Dev. 2, 2003, 1-6.

[3] M. Pugalenthi, V, V. Gurumoorthi and P. Janaardhanan. Comparative nutritional evaluation of little known legumes Tamarindus indica, Erythrina indica and Sesbania bispinosa. Trop. Subtrop. Agroecosyst, 4, 2004, 107-123.

[4] D. B. Oke, O.O. Tewe and B.L. Fatuga, The nutritional composition of some Cowpea varieties. Nigeria Journal of Animal Production. 22, (1), 1994, 32-36.

[5] A. D. Ologhobo, Biochemical and Nutritional studies of cowpeas and Lima bean with particular reference to some inherent anti-nutritional factors, doctoral diss., University of Ibadan, Ibadan, Nigeria, 1980.

[6] A. S. Abitogun and E. G. Olumayede, Extraction and characterization of Luffa cylindrical oil. Journal of Applied Sciences, 28, 2008, 112-119.

[7] R. R. Del Rosario, Y. Lozano and M. J. Noel, The chemical and bio-chemical composition of legume seeds. Philippine Agriculturist, 64, 1981, 49-57.

[8] O. Olaofe, B.Y. Olukitibi and M.O. Aremu, Chemical evaluation of the nutritive value of smooth Luffa (Luffa cylindrica) seed' kernel. EJERAF Che, 7 (10), 2008, 3444-3452.

[9] P. Siddihuraju, K. Vijayakumari and K. Janardhanan, Chemical composition and nutritional evaluation of an under exploited legume, Acacia nilotica (L) Del. Food Chemistry, 57 (3), 1996, 385 -391.

[10] A.B.I. Udedibe, Nutritional evaluation of Jack bean (Canavalia ensiformis) for the Nigerian Poultry Industry. AMB 1019(8), 1990, 361-365.

[11] R. Sanchez-Vioque, A. Clement, J. Vioque, J. Bautista and F. Millian, Polar Lipids of defatted Chickpea (Cicer arietium L) flour and protein isolates. Food Chemistry, 63, 1998, 357-855

[12] United State Department of Agriculture (USDA), (Canavalia ensiformis (L) DC. Germplasm Resources Information Network, 2005.

[13] A.O.A.C. Official Method of Analysis of the Association of Analytical Chemist Washington D. C. USA. 1992, 1250-1255

[14] D. Pearson, The chemical analysis of foods (Churchill Living stone, 1976) 200-222.

[15] ASTM, American Society of Testing Materials, ASTM Publications, 1985, 31-48.

[16] G.E.A. Costa, K. S. Queiroz-Monici, S.M.P. Machado Reis and A.C. Oliveira, Chemical composition, dietry fibre and resistant starch contents of raw and cooked pea, common bean, chickpea and lentil legumes. Food Chemistry, 94, 2006. 327-330.

[17] A.A. Oshodi, O. Olaofe and G.M. Hall, Amino acid, fatty acid and mineral composition of Pigeon pea (Cajanus cajan). Inter. J. Food Sci. and Nutri. 43, 1993, 187-191.

[18] R.A. Oderinde, I.A. Ajayi and A. Adewuyi, Characterization of the seed and seed oil of Hura crepitans and the kinetics of degradation of oil during heating. Electronic Journal of Environmental Agricultural and Food Chemistry, 8, 2009. 201-208.

[19] L.E. Cruz-Suarez, D. Ricque-Marie, M. Tapia-Salazar, I.M. McCallum and D. Hickling, Assessment of differently processed feed pea (Pisum sativum) meal and Canola meal (Brassica sp) in diets for blue shrimp (Litopenaeus stylirostris). Aquaculture, 196, 2001, 87-104.

[20] E.A. Olayemi, A.A. Akinola, A.A. Adenuga and M.B. Adebayo Mineral contents of some commonly consumes. Nigerian Foods. Sci. Focus. 11, (1), 2006, 153-157.

[21] D.M. Dreon, K.M. Vranizan, R.M. Krauss, M.A. Austin and P. D. Wood, The effects of polyunsaturated fat and monounsaturated fat on plasma, Lipoproteins. J. Am. Med. Assoc., 263, 1990. 2462.

[22] A. S. Abitogun and A. A. Oshodi, Effects of degumming and bleaching on the Physicochemical parameters of crude Sunflower oil. J. Chem. Soc. Nigeria. 35, (2), 2010, 57-61.

[23] D. K. Salunkhe, R. N. Chavanand and S. S. Adsule-Kadam, World Oilseeds, Chemistry Technology and Utilization (Van Nortrand Rainhold, New York, 1992).

[24] A. S. Abitogun, O. A. Seyifunmi, V. E. Adebote and A.C. Omosheyin, Nutritional and chemical composition of Pigeon Pea (Cajanus cajan) flour and oil. Journal of Environmental Planning and Development, 2, (1), 2010, 33-36.

[25] I.O. Eromosele, C.O. Eromosele and D. M. Kuzhkuzha, Evaluation of mineral elements and ascorbic acid contents in fruits of some wild plants. Plant Hum., 41, 1991, 151-154.

[26] J. S. Garrow, W.P.T. James and A. Ralph, Human nutrition and Dietetics (Churchill Living Stone, New York, 2000) 703.

[27] M. M. Baker, Nutrition and Dietetics for Health Care (Churchill Living Stone, New York, 1996) 92-101.

[28] U. Melaku, E.W. Clive and Habtamon, Content of Zinc, Iron, Calcium and their absorption inhibitor in foods commonly consumed in Ethiopia. J. Food Composition. Anal. 18, 2005, 803-817.

[29] National Health and Medical Research Council (NHMRC). Recommended dietary intakes for use in Australia (Australia Government Publishing Service and Canberra ACT 2601, 1991)

[30] A. S. Abitogun, A. O. Jide, G. Aladekoyi and F. B. Borokini, Quality evaluation and antimicrobial activities of Shea Butter (Vitelleria paraosum). J. Chem. Soc. Nigeria, 36, ( 2), 2011, 147-151.

[31] M.T. Howard, Fat and Oil, Mc Graw-Hill, Encyclopedia of Science and Technology, $8^{\text {th }}$ Ed. Mc Graw-Hill Inc. USA. 7, 1997 , $17-23$.

[32] H.M. Lillian, Food Chemistry (West port Connecticut 1960, Litton Educational Publishing Inc. Van Nostrand Reinhold New York, 1978) 12-60.

[33] A. S. Abitogun, A.O. Jide, J.O. Arawande and A.C. Omosheyin, Effects of Phosphoric acid on the physicochemical parameters of Soya bean oil. The internet Journal of Nutrition and Wellness, 8, (2), 2009, 1-8.

[34] F. D. Gunstone, Occurrence and characterization of Oil and Fats, in Vegetable Oil in Food Technology, Ed., (Blackwell Publishing, Oxford UK 2004.)

[35] S.O. Ibiyemi, T.O. Adepoju, S.O. Okanlawon and V.O. Fadipe, Emulsion preparation and stability. Journal of Nutritional Science. 13: (1-2), 1992, 31-34.

[36] Abitogun and O. F. Badejo, Physicochemical parameters and antimicrobial activities of oil extracted from Ginger. Ethnobotanical Leaflets, 14, 2010, 381-389.

[37] D. J. Gibb, P.S. Owens, M. Mir and T. A Ivan-MacAllister, Value of Sunflower seed in finishing diets of feedlot Cattle. J. Anim. Sci., 82, 2004, 2676-2692. 